\title{
"Burnout" Animasi Dua Dimensi Dengan Teknik Rotoscope
}

\author{
Fauzi Rahman ${ }^{1}$, Mahendradwea Suminto ${ }^{2}$, Pandan Pareanom Purwacandra ${ }^{3}$ \\ Program Studi Animasi, Fakultas Seni Media Rekam, \\ Institut Seni Indonesia Yogyakarta \\ e-mail: fauzirahman@gmail.com ${ }^{1}$, mahendrads@isi.ac.id ${ }^{2}$, \\ pandan@isi.ac.id ${ }^{3}$,
}

\begin{abstract}
Abstrak
Film sebagai media kominikasi massa mempunyai andil yang cukup besar pada masyarakat era digital ini. Animasi merupakan jenis film yang menaik sebagai alternative dari film live shot. Pembuatan film animasi sebagai media komunikasi yang menarik diharapkan mampu menyampaikan gagasan cerita serta memberikan kontribusi positif bagi penonton.

Penggunaan teknik rotoscope dalam produksi film animasi ini dikarenakan gagasan atau konsep yang ingin disampaikan dalam cerita mempunyai kesesuaian. Cerita yang disampaikan merupakan kehidupan nyatan dan teknik rotoscope menghasilkan visual yang cukup realis. Teknik ini juha mempunyai kelebihan efisiensi waktu produksi karena teknik ini merupakan teknik menjiplak gambar dari video aslinya. Penggunaan teknik ini pada karya film ini dapat menambah keberagaman teknik pada produksi film khusunya animasi di Indonesia.

Produksi film animasi Burnout ini menceritakan tentang pelarian seseorang terhadap masalah-masalah pribadinya yang hanya ada didalam pikirannya. Membangun motivasi diri untuk menghadai masalah ayng ada menjadi tujuan dalam film animasi Burnout ini.
\end{abstract}

Kata kunci: Film, Animasi, Rotoscope, Burnout

\begin{abstract}
Film as a medium of mass communication has a considerable share in this digital era society. Animation is an upgraded movie type as an alternative to a live shot movie. Making animated films as an interesting communication media is expected to convey the idea of the story as well as make a positive contribution to the audience.

The use of rotoscope techniques in the production of animated film is because the idea or concept to be conveyed in the story has a suitability. The story delivered is a life nyotos and rotoscope techniques produce fairly realistic visuals. This technique has the advantage of efficiency time juha production because this technique is a technique to trace the image of the original video. The use of this technique in the work of this film can increase the diversity of techniques in film production especially animation in Indonesia.

Burnout animated film production is about a person's escape to his personal problems that only exist in his mind. Building your self-motivation to come into trouble is a goal in this Burnout animated film.
\end{abstract}

Keywords: Film, Animation, Rotoscope, Burnout 